\title{
THE ACTION OF STEROID HORMONES AT THE CELLULAR LEVEL
}

\author{
P. F. DIXON, B.A., M.B., B.Chir., A.R.I.C., \\ C. H. GRAY, M.D., D.Sc., F.R.C.P., F.R.I.G \\ R. V. QUINCEY, B.A.
}

Department of Chemical Pathology, King's College Hospital Medical School, London, S.E.5.

Although the complex series of events which occur when a steroid hormone is administered to a human subject or to an intact animal might reflect a series of completely unrelated activities, they are more likely to be secondary to a few fundamental actions on the cells of the body and it is with this second concept that research in this field has been directed.

There are two particular features of steroids which may be important in determining their mode of action. Firstly, they have oxygen substituents at certain typical positions which readily undergo enzymatic oxido-reduction and could, therefore, act as coenzymes or prosthetic groups of enzymes in reactions involving hydrogen transfer. Secondly, steroids are surface active and interact with hydrophobic surfaces producing energy. If the energy were to be absorbed by a receptor molecule it could modify the structure and hence the biological activity of that molecule. A less well defined change is associated with the ability of steroids to capture electrons; this has recently been measured by Lovelock, Simmonds and Vandenheuvel (1963) who consider that the high electron affinities of adrenocortical hormones, a property unusual among organic compounds, might indicate their ability to participate in or control biological oxidative processes.

Laidler and Krupka (1961) compared the association between the steroid and a receptor with the formation of an activated enzymesubstrate Michaelis complex. Entropy and volume changes during activation of enzymes indicate that structural changes occur in the enzyme molecule and such changes might explain the disturbances of membrane permeability in nerve cells associated with structural changes in acetylcholinesterase. A similar mechanism might account for changes induced by steroids in the permeability of cell structures.

In this process parts of the receptor molecules having specific binding properties might be masked, unmasked, created or destroyed; as well as causing a redistribution of bound substrates, an alteration in enzymic properties might result. Kimberg and Yielding (1962) studied the inhibition of pyruvate kinase by oestrogens and related compounds and showed by viscometry and electrophoresis structura changes in the enzyme, without a change in molecular weight. Yielding and Tomkins (1962) have reported a steroid-hormone induced loss of activity of crystalline glutamic dehydroz. genase due to disaggregation into subunits functioning as alanine dehydrogenase with an uncovering of pyridine-nucleotide binding sites These authors have been more concerned t $\%$ show the possibility of such changes rathero than to attach great physiological significancs to them. Chemical changes in receptor molecules after association could account for the highly theoretical possibility of the formation of active enzymes from inactive precursors. $\stackrel{5}{+}$

That the receptor itself could be an enzyen cofactor has been considered by Scott Engel (1961) who obtained physical evide ic for the interaction between steroid hormones and purine dinucleotides. This interaction between hormone and a coenzyme associate with a postulated change in the structures of the coenzyme might abolish its hydrogen carrying function, but there was no experî mental evidence for this.

Apart from oxido-reductive changes metabolism of the steroid molecule is not thought to be of physiological importances except as a mechanism for steroid inactivation. However, competition for active sites o enzymes as opposed to association with them could be of importance in influencing steroid metabolism itself.

The various theories which have been pro? posed to explain the action of steroid hormones at the cellular level will be considered under the following headings:

1. Effects on membrane permeability and active transport.

2. Effects on hydrogen transfer.

3. Effects on enzyme induction and protei synthesis.

Effects on Membrane Permeability and on Active Transport.

Roberts and Szego (1953) found that œstro gens increased the glucose uptake of rat uter 
and suggested that their primary action might be to facilitate the entry of glucose into the uterine cells. Noall, Riggs, Walker and Christensen (1957) showed an increased uptake of $\alpha$-amino-iso-butyric acid (AIB) in immature rat uteri 20 hours after administering œstradiol and in rat liver 2 hours after giving hydrocortisone. Since this synthetic amino acid is not metabolised, any change in uptake must be due to a change in transport. Halkerston, Eichhorn, Feinstein, Scully and Hechter (1960) examined the effects of cestradiol on the uteri of castrate rats using intravenous $\left[{ }^{14} \mathrm{C}\right]$ labelled AIB as well as $\left[{ }^{14} \mathrm{C}\right] \mathrm{D}$-xylose; they found no change $1 \frac{1}{2}$ hours after œstrogen injection, although the metabolic effects on glucose uptake and incorporation of amino acids into protein are detectable after one hour. After six hours there was an increase in the water content of the tissue and a small increase in AIB and xylose accumulation. They concluded that there is no primary change in sugar or amino acid transport and interpreted previous results as secondary effects operating at a later time. On the other hand Noall and Allen (1961) obtained more than 100 per cent increase in AIB uptake in uteri in vitro removed only 30 minutes after intravenous administration of œstradiol to immature rabbits. They comment that in vivo experiments were unsuitable for the investigation of early changes. No effect was observed when the excised uteri were treated wth cstradiol in spite of adequate penetration of the hormone. Although this suggested that the increased uptake observed after in vivo hormone administration may not have been a primary effect, they postulated that œstradiol might be metabolised to a hypothetical active form but their evidence was inconclusive. An increased uptake of AIB by rat levator ani muscles after large doses of testosterone and of synthetic anabolic steroids was shown by Metcalf and Gross (1960) but the effects were not observed until 39 hours after the injection of the steroid and nine hours after AIB administration. Increased AIB uptake in isolated perfused rat livers was seen by Bass, Chambers and Richtarick (1963) two hours after both in vivo and in vitro administrations of hydrocortisone, suggesting an early direct effect on liver cells.

It is reasonable to conclude that steroid hormones alter transport mechanisms and thus influence the availability of substrate to cells, but although early effects have been observed in isolated organs it is not certain that these are primary events. Since cells are now regarded not as bags of assorted enzymes but as highly organised structures, parts of which are clearly differentiated by membranes and phase boundaries, a possible effect on intracellular substrate distribution must also be considered. Information on this, however, is scanty and indirect. Binding to subcellular particles has been studied by Westphal (1961) who demonstrated interaction between liver mitochondria and hydrocortisone and corticosterone, and by Bellamy (1963) who showed a significant binding between corticosterone and rat liver ribosomes. There is definite evidence that the mitochondrial membrane is influenced by steroids. Westphal (1961) found that hydrocortisone and corticosterone increased the swelling of rat liver mitochondria, indicating an increased permeability to water. Gallagher (1960) concluded that hydrocortisone inhibited oxidative metabolism in liver mitochondria by increasing the membrane permeability causing loss of respiratory cofactors. Blecher (1962) suggested that a similar swelling was associated with a release of latent ATPase which inhibited metabolism of glucose by reducing the availability of ATP. He cited this as a mechanism for the lymphocytolytic action of steroids.

Structural alterations in the peripheral cello membrane are generally assumed to account for changes in transport (see Tomkins andôㄱ Maxwell, 1963). Controlled and variable passive diffusion can be explained on a biochemical basis, but explanations of mechanisms of active transport in which energy is used to transfer molecules against concentration gradients are only speculative. Hechter and Lester (1960) present and review data suggesting that part of the increased glucose uptake of muscle cells in response to insulin is the apparent removal of intracellular barriers to diffusion, enabling the sugar to equilibrate in a larger fraction of the cell water. Extending this theory the authors outline a model cell based on the results of their experiments on sodium and potassium distribution in the mould Neurospora Crassa. Potassium was taken up against a concentration gradient and sodium was excluded from the major part of the cell water, but in the presence of desoxycorticosterone both ions were distributed in all of the cell water at the same concentration as in the surrounding medium. This suggested that the sodium pump operated not at the cell boundary but in the cytoplasm. The crystal structure of certain silicate minerals excludes the highly hydrated sodium ions, whereas the less hydrated potassium ions are able to diffuse freely through and be adsorbed by the lattice; 
such minerals behaved in a similar manner to untreated Neurospora. The authors assumed that in the cytoplasm there are ordered lattices which require energy to maintain their structures and which bind potassium ions and water molecules and exclude sodium ions. In the absence of energy or under the influence of specific agents the lattices expand, potassium binding sites are lost and sodium is no longer excluded. Other cytoplasmic components may also bind sugar and amino acid molecules. The bound substrate equilibrates with substrate in the non-bound intracellular water and at equilibrium the concentration of this equals that of the surrounding medium. Active transport in this model is the binding of substrate and water to the lattice with equilibration of the unbound intracellular phase with the surrounding medium through an inert membrane. In spite of the authors' assertions to the contrary, sufficient binding of potassium to account for active transport is thermodynamically inconsistent with the maintainance of an electrical potential across the membrane. However, the ability of this ingenious model to account for many aspects of active transport merits serious consideration.

\section{Effects on Hydrogen Transfer}

Several steroids inhibit the transfer of hydrogen from the pyridine nucleotide coenzymes by the mitochondrial cytochrome chain (see Wade and Jones, 1956) reducing respiration and oxidative phosphorylation. Yielding, Tomkins, Munday and Cowley, (1960) located the site of action between flavoprotein and cytochrome b; Chance and Hollunger (1963) found that inhibition of respiration by progesterone was sensitive to reagents such as dinitrophenol which uncouple the oxidative and phosphorylation processes, and concluded that the actual site of inhibition was in the energy-transfer process. They postulated that the inhibitor binds a high-energy intermediate and that the uncoupling reagent dissipates this complex with loss of its energy.

Oestrogens stimulate respiration in their target tissues. Hagerman and Villee (1957) studied placental respiration and identified an oestrogen-sensitive isocitric dehydrogenase. This Krebs cycle enzyme requires NADP as coenzyme, but it was at first thought that the oestrogen-sensitive enzyme utilised NAD; later the oestrogen-sensitive step was discovered to be the transfer of hydrogen from NADPH to NAD (Talalay, Hurlock and Williams-Ashman 1958), the rate-limiting factor in the Krebs cycle being the availability of NADP: -

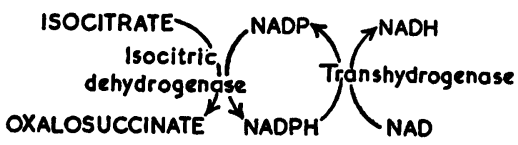

Transhydrogenases, which catalyse the trans $\stackrel{\overrightarrow{5}}{\stackrel{\overrightarrow{7}}{0}}$ fer of hydrogen between pyridine nucleotid $\tilde{E}^{\circ}$ coenzymes, have been identified in both mito chondria and in soluble cell sap of severab tissues and organisms. The transfer of hydrogeno from NADPH to NAD increases the efficiency, of energy production since NADH transfers its hydrogen to cytochrome $\mathrm{c}$ via flavoprotein $\overrightarrow{\vec{\omega}}$ coenzyme $\mathrm{Q}$ and cytochrome $\mathrm{b}$ with a greatee yield of ATP than NADPH which transfers hydrogen directly to cytochrome c. They may. also play important regulatory roles in cellularo metabolism, as NADP may be a rate-limitings factor in dehydrogenations in the pentose phosphate cycle and the availability of NADPH may influence fatty acid and steroid biosyn? thesis and hydroxylations. In addition to the œstrogen-sensitive transhydrogenase, which? Hagerman and Villee (1961) claim can be found in all œstrogen target organs, Hurlock $\stackrel{\text { s }}{+}^{-}$ and Talalay (1958) have described a 3-hydrox $\overrightarrow{0}$ steroid-sensitive transhydrogenase system an liver, but which is probably only of minotio

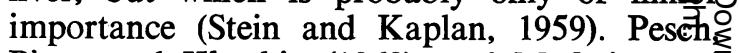
Piros, and Klatskin (1962), and McGuire anof Pesch (1962) have identified steroid-sensitive transhydrogenases in particulate preparations $\Omega_{\mathscr{D}}^{\circ}$ of liver and anterior pituitary.

The mechanism of steroid-sensitive trans $-\frac{9}{-}$ hydrogenation is the subject of some dispute? Talalay and Williams-Ashman (1958) proposed? a dehydrogenase system having dual nucleotideo specificity with the transfer occurring via the steroid which is alternately reduced and? oxidised:-

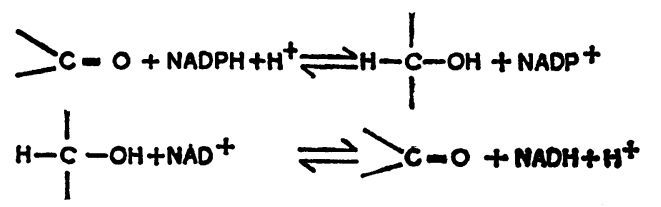

the nett reaction being:

$$
\mathrm{NADPH}+\mathrm{NAD}{ }^{+} \rightleftharpoons \mathrm{NADP}++\mathrm{NADH}
$$

Hagerman and Villee (1959) consider thates the placental transhydrogenase is stimulated by $17 \beta-\mathrm{OH}$ œstrogens but that they take no directo part in the reaction and using starch-gel electro- 
phoresis they claimed to separate dehydrogenase activity from transhydrogenase activity, although in small yield. Williams-Ashman, Jarabak, Adams and Talalay (1962) purified the placental enzyme 2,500-fold with an overall yield of 29 per cent and could not separate dehydrogenase from transhydrogenase activity at any stage. Moreover the stilbostrol derivtives, having only phenolic oxygen groups, should be inactive if the dehydrogenase theory is correct. Adams, Jarabak and Talalay (1962) reported that with the purified enzyme, diethylstilbœstrol acted as a competitive inhibitor. However Abe, Hagerman and Villee (1964) working with an enzyme isolated from myometrium found only slight dehydrogenase activity and that diethylstilbœstrol was fully active in stimulating transhydrogenation. Whatever the mechanism, œstrogen-stimulated transhydrogenation undoubtedly occurs, and Joel, Hagerman and Villee (1961) present data supporting. but not proving, the hypothesis that increased ATP production after stimulation of transhydrogenation directly influenced the synthesis of cell constituents.

Lucas, Neufield, Utterback, Martin and Stotz (1955) reported that œstrogens stimulate uterine peroxidase activity and WilliamsAshman, Cassman and Calvins (1959) have found a possible hydrogen transfer by purely phenolic compounds in model systems utilizing peroxidase. Talalay and Williams-Ashman (1960) have isolated such a system from uteri and shown an œstrogen-mediated increase in oxidation, but its physiological significance is doubtful.

Bush (1962) considers that chemical changes in steroid molecules are not related to their function and represent metabolism and inactivation only. He has examined particularly the 11-oxygen function and from a study of hydrocortisone analogues has concluded that the $11 \beta$-hydroxyl group is the only essential requirement for glucocorticoid activity; particularly significant is the finding that $9 \alpha$-fluorohydrocortisone does not give rise to 11 -oxo metabolites, and it therefore seems unlikely that oxidation plays any part in its biological activity since this fluoro compound is many times more active than hydrocortisone.

\section{Effects on Enzyme Induction and Protein Synthesis}

The administration of œstrogens to females causes a rapid increase in uterine weight and administration of androgens to males causes an increase in the weights of the secondary sex organs and of other sensitive tissues. The increase in weight is due largely to protein although in the uterus there is also a rapid uptake of water. Glucocorticoids cause a net decrease in peripheral-tissue protein whilst appearing to enhance protein synthesis in the liver. In addition to the general weight response of target tissues to œstrogens or androgens, administration of these hormones increases the effective concentration of many enzymes and glucocorticoids increase the effective concentration of some liver enzymes. The response to androgens and probably to other steroid hormones is highly dependent on both tissue and species.

Induced enzyme synthesis. The effect of steroid hormones on protein synthesis is most easily studied by determining changes in enzyme activity because of the ease with which small net changes may be measured. An increase in activity of an enzyme after steroid administration could be due to either enzyme activation or an increase in enzyme synthesis, i.e. enzyme induction. Induction, however, might not necessarily be a primary action of the steroid but could be secondary to some other action of the steroid in modifying the intracellular environ ment. Much experimentation has been designed to establish whether there is activation ofo induction, often by immunological studies.

The effect of testosterone on the activity of mouse kidney $\beta$-glucuronidase has been studied by Riotton and Fishman (1953). The activity of this enzyme after treatment of the animal with testosterone showed a thirtyfold increase and could be maintained at this level for 60 days by continued testosterone administration. The response was later attributed to an increase in enzyme synthesis because the specific activity of $\beta$-glucuronidase isolated from the kidneys of mice treated with testosterone and given $\left[{ }^{14} \mathrm{C}\right]$-glycine was higher than that from the kidneys of untreated mice or the livers of both treated and untreated animals (Pettengill and Fishman, 1960). Tryptophan pyrrolase activity in liver is stimulated by the administration of hydrocortisone to rats but this increase is prevented by simultaneous administration of the methionine analogue ethionine (Horton and Franz, 1959); in perfused-liver preparations the increase occurs after the hydrocortisone has disappeared (Goldstein, Stella and Knox, 1962). The increase in enzyme activity is, therefore, a result of increased enzyme synthesis.

Hydrocortisone produces a rapid increase in tyrosine- $\alpha$-ketoglutarate transaminase activity in perfused rat-liver preparations (Goldstein 
and others, 1962). Kenney (1962a) has purified this enzyme and shown that there are both active and inactive enzyme components but the proportions of active and inactive components were the same in preparations from both control and hydrocortisone-treated animals. He concluded that hydrocortisone did not promote the conversion of an inactive enzyme form to the active form and he also showed (Kenney 1962b) that the rise in enzyme activity was paralleled by a rise in antigenic material suggesting that increased enzyme synthesis was primarily responsible for the hydrocortisone-induced increase in activity. Kenney and Flora (1961) showed that the increase in activity was related to the concentration of steroid in the liver and believed that the steroid was acting directly on the protein-synthesising system.

Glutamic-pyruvic transaminase activity in rat liver is increased by hydrocortisone administration and this increase could be inhibited by ethionine (Segal, Beattie and Hopper, 1962). Segal, Rosso, Hopper and Weber (1962) have shown that the rise in enzyme activity is paralleled by an increase in antigenic material again suggesting that the hormone induces enzyme synthesis. However, fasting, diabetes or a high protein diet also increases hepatic glutamic-pyruvic transaminase activity (Rosen, Roberts and Nichol, 1959) which suggests that the observed increase may be secondary to a peripheral effect. Similarly, although hydrocortisone increases glucose-6-phosphatase activity in the livers of adrenalectomized or normal rats so does starvation or a high protein diet (Harper and Young, 1959; Harper, 1959) or alloxan diabetes (Froesch, Ashmore and Renold, 1958).

Effects on uptake of amino acids. Several workers have studied the uptake of radioactive amino acids by target tissues after estrogen or androgen administration. Frieden, Laby, Bates, and Layman (1957) showed that the uptake of $\left[{ }^{14} \mathrm{C}\right]$-glycine into mouse kidney was stimulated by testosterone propionate and Butenandt, Gunther and Turba (1960) showed that the incorporation of $\left[{ }^{14} \mathrm{C}\right]$-leucine by seminal vesicles of immature rats receiving testosterone was increased fourfold whilst Mueller (1961) has shown that the amount of radioactivity in protein was greater in uteri from cstradiol-treated rats after $\left[{ }^{14} \mathrm{C}\right]$-glycine administration. Mueller (1961) also showed that the incorporation of radioactivity from $\left[{ }^{14} \mathrm{C}\right]$ glycine into nucleic acid adenine and of ${ }^{82} \mathrm{P}$ into phospholipid of uteri was increased when rats were treated with ostradiol. Puromycin in- hibited these effects of œstradiol. He concludeक⿱乛龰 that ostradiol-stimulated protein synthesis and that the effect of puromycin on the incorpora 2 tion of radioactivity from glycine into nucleic. acid adenine and of phosphorus into phospho lipid was due to an inhibition of the enzymes responsible for adenine and phospholipief synthesis. Such experiments do not define the step in protein synthesis on which steroids actô

Wilson (1962a) in an attempt to define this more closely has studied the rise in specific activity of free intracellular tyrosine and $o \vec{B}$ protein during incubation of slices of $\mathrm{raF}$ seminal vesicles with $\left[{ }^{14} \mathrm{C}\right]$-tyrosine. $\mathrm{H} \mathrm{eg}^{\mathrm{m}}$ concluded that testosterone did not act by enhancing amino acid transport and that the increase in amino acid incorporation was secondary to an increased protein synthesis Effects on amino acid activation. Steroids may not only act directly on amino acid transpor (see above) but have been shown to increase also the activity of some amino-acid-activating enzymes, which are essential for the synthesis of protein. Thus, Mueller, Herranen and Jervel[ (1958) have shown that cestradiol causes an early increase in the activity of seven of the known amino-acid-activating enzymes a d Kochakian, Tanaka and Hill (1961) ha $e^{+}$ shown that the activity of amino-acid-activating enzymes in the seminal vesicles of guinea pigs was reduced 40 per cent 40 days after castra tion. The activity could be restored by androgens.

Effects on ribosomal activity and the formation $\overrightarrow{\vec{P}}$ of ribonucleoprotein. Much recent work on steroids has been designed to define their exace role in protein synthesis, the main steps of which are outlined in Figure 1.

Amino acids are activated in the cytoplasm by specific amino-acid-activating enzymes and can then. complex with specific soluble ribonucleic acio molecules (s-RNA). The s-RNA-amino-acid complex which is formed is transferred to a specific position on an RNA template situated on the surface of a ribosome. Peptide-bonding of the amino acidos attached to the template occurs and is followed bs release of the newly formed protein from the template. The genetic determination of the structures of a protein is due to the synthesis of that protein on a ribosomal RNA template whose base sequence if determined by that of the deoxyribonucleic acid (DNA) of the structural gene. The template oO messenger RNA is synthesised in the nucleus and transferred to a ribosome; its rate of synthesis if determined by an operator-repressor gene system (Jacob and Monod, 1961). The operator is normally ${ }^{+}$ inhibited by the repressor and cytoplasmic inducerso act by reducing the inhibitory action of the repressor on the operator. Since the ability of ribosomes tơ synthesise protein is related to its template RNA? 


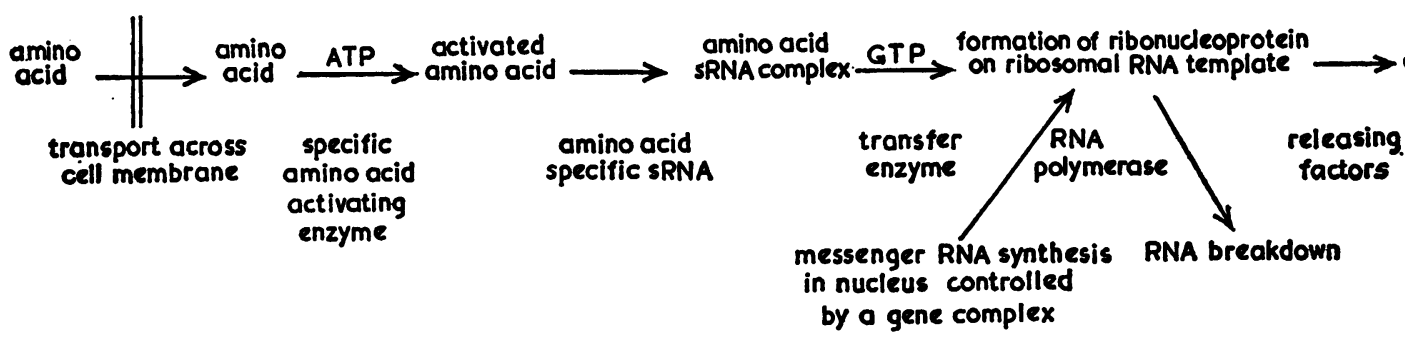

Fig. 1.-The Biosynthesis of Protein.

content protein synthesis will be affected. Steroids could act on protein synthesis by regulating the availability of template RNA through control of its rate of synthesis or breakdown, or alternatively by modifying ribosomal structure as Tissières, Schlessinger and Gros (1960) have shown that this is important in determining the rate of protein synthesis in bacterial systems.

Wilson (1962a) investigated the effect of testosterone administration on the increase with time in specific activity of ribosomal protein and s-RNA-amino-acid complex in slices of seminal vesicle incubated with $\left[{ }^{14} \mathrm{C}\right]$-tyrosine or $\left[{ }^{14} \mathrm{C}\right]$-leucine. He found that testosterone accelerated the rise in specific activity of ribosomal protein but did not affect the rise in specific activity of the s-RNA-amino-acid. He concluded that testosterone acted by enhancing the formation of ribonucleoprotein on the ribosomes and in similar experiments on the effect of œstradiol on protein synthesis in rat uterine slices, Wilson (1962b) showed that œstradiol also acted on this step. Using preparations of ribosomes and soluble factors isolated from the oviducts of cestradiol-treated or control hens, Wilson (1962b) showed that œstradiol modified ribosomal activity but did not affect the activity of the soluble factors required in the formation of ribonucleoprotein.

The action of glucocorticoids on protein synthesis in the liver has also been defined at the ribosomal level by Korner (1960) who showed that ribosomes from the livers of rats adrenalectomized some weeks previously were less active than those of controls. Treatment of normal rats with hydrocortisone increased liver ribosome activity. The immediate effect of adrenalectomy, however, was to increase ribosomal activity and this could be abolished by treatment with hydrocortisone. The activity of the soluble factors was unchanged during these procedures. These paradoxical early and late effects of adrenalectomy have not yet been explained.

Effects on synthesis of template (ribosomal) ribonucleic acid. Mueller (1961) has shown that increased nucleic acid synthesis is an early effect of œstrogen treatment; Kochakian, Hill and Aonuma (1963) have found that template RNA from mouse kidney, but not soluble RNA, was increased by testosterone propionate administration and Cantarow, Pashkiss and Williams (1959) have found that the administration of testosterone increased $\left[{ }^{14} \mathrm{C}\right]$-uracil incorporation by rat liver and hepatoma cells. More directly, Hancock, Zelis, Shaw and Williams-Ashman (1962) have shown that the incorporation of radioactive cytosine triphosphate into RNA by DNA-dependent RNA polymerase from the nuclei of rat ventral prostate was decreased in preparations from castrated rats and the activity could be restored by treating the rats with testosterone. These experiments show that steroids increase the synthesis of template RNA.?

Work on the inhibition of induced enzyme synthesis by 8 -azaguanine (which prevents RNA synthesis) and by actinomycin (which prevents the messenger RNA from attaching to the ribosomes) has shown that the synthesis of template RNA and its attachment to the ribosomes are necessary for induced enzyme synthesis. Thus, Kvam and Parkes (1960) have shown that the simultaneous administration of 8-azaguanine and hydrocortisone to adrenalectomized rats prevented the increase in glucose6-phosphatase and fructose 1, 6-diphosphatase which normally occurred after hydrocortisone administration. Similarly Greengard and Acs (1962) showed that actinomycin prevented the rise in tryptophan pyrrolase and tyrosine- $\alpha-$ ketoglutarate transaminase activity after hydrocortisone administration. However, chloramphenicol, which inhibits protein synthesis in bacteria and is thought to act by preventing the messenger RNA from attaching to the ribosomes, does not inhibit the incorporation of $\left[{ }^{14} \mathrm{C}\right]$-leucine into kidney ribosomes from testosterone-treated mice (Kochakian and others, 1963) nor does it inhibit protein synthesis in the oviduct system of hens treated with œstradiol (Wilson, 1962b). This does not invalidate the

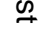

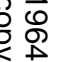


view that steroids act by increasing the synthesis of template RNA, but shows that there is not a high turnover of labile messenger RNA sensitive to chloramphenicol inhibition as in bacteria.

Direct evidence that steroids act on protein synthesis by regulating the availability of template RNA has been obtained by Liao and Williams-Ashman (1962). They found that the transfer of radioactivity from s-RNA-valine$\left[{ }^{14} \mathrm{C}\right]$ to trichloracetic acid-insoluble material by ribonucleoprotein particles from rat ventral prostate was markedly reduced in preparations from animals castrated 2-3 days previously and the activity could be increased threefold by the addition of polyuridine-guanidine (UG), a synthetic polynucleotide having a high uracil/ guanine ratio. The administration of testosterone to the animals completely reversed the effects of castration and the addition of polyUG to preparations from testosterone-treated castrates had no effect. On the other hand, Wilson (1962b) found that the addition of ribosomal RNA, extracted from the oviducts of hens treated with estradiol, to the proteinsynthesising system from the oviducts of untreated hens did not increase the rate of protein synthesis. However, the RNA might have been degraded during the extraction procedure.

Effects of glucocorticoids on protein synthesis in peripheral tissues. The glucocorticoid-induced decrease in peripheral-tissue protein seems to be due to a decreased rate of synthesis rather than to an increased rate of breakdown. Manchester, Randle and Young (1959) showed that adrenalectomy raised, whilst hydrocortisone depressed, the rate of incorporation of $\left[{ }^{14} \mathrm{C}\right]$ glycine into protein of rat diaphragm and White, Hoberman and Szego (1948) showed that the rate of incorporation of $\left[{ }^{15} \mathrm{~N}\right]$-glycine into muscle and some other tissues was increased by adrenalectomy. From a study of the rate of excretion of isotopic nitrogen after the administration of $\left.{ }^{1{ }^{15}} \mathrm{~N}\right]$-glycine to normal, adrenalectomized and adrenalectomized rats treated with cortisone, Clarke (1953) concluded that cortisone acted by inhibiting synthesis rather than by promoting protein breakdown. $\frac{\mathbb{Q}}{\mathrm{D}}$

\section{Conclusions}

Many of the physiological effects of steroids on electrolyte distribution and on the avaiff ability of cellular substrates might result from a single action of these hormones on active transport. Although the exact mechanism of active transport is unknown, the theory of Hechter and Lester is interesting. Steroids could interact with those intracellulas structures which are involved in the transpoitt mechanism, modify their structure and hence the uptake of substances by the cell. Howeve the uptake of substrate by cells is probably no rate-limiting in all cases and steroids certain 18 affect the activity of many intracellular enzyme systems so that an apparent action on transpot could be secondary to some other action on ap intracellular enzyme system.

Steroid-activated enzyme systems which catalyze transhydrogenation occur in many tissues but their presence in all cestrogen target tissues is questionable (Mueller, 1961) which throws doubt on their physiological significance The mechanism proposed by Talalay for trages hydrogenation is the only example of chemiea change in the steroid molecule being importangt in its mode of action.

The action of steroids on protein synthesis with the possible exception of the influence of glucocorticoids on peripheral tissues, probably to regulate the synthesis of messenge? RNA, perhaps through the operator-repressoo gene system. Such a mechanism permits specifie enzyme synthesis and a differentiation in tissug response because in different tissues enzymes with similar functions may have differen structures (Kaplan, Ciotti, Hamolsky and Bieber, 1960) and hence be controlled by different gene complexes. However, the increase in synthesis of some enzymes after steroid administration might not be due to a direct action of the steroid on the protein-synthesising mechanism but could be secondary to some other change in cellular environment.

\section{REFERENCES}

Abe, T., Hagerman, D. D., and Villee, C. A. (1964): Estrogen-Dependent Pyridine Nucleotide Transhydrow

genase of Human Myometrium, J. biol. Chem.; 239, 414.
AdaMS, J. A., JARABAK, J., and TALALAY, P. (1962): The Steroid Specificity of the 17 $\beta$-hydroxysteroid Dehydrogenase of Human Placenta, J. biol. Chem., 237, 3069. Bass, A. D., ChAMBERS, J. W., and RICHTARICK, A. A. (1963): The Effect of Hydrocortisone on AIB Uptak恳 Bellamy, D. (1963): The Adsorption of Conticosteroids to Particulate Preparations of Rat Liver, Biochemp
J., 87, 334. BLECHER, M. (1962): Effect of Deoxycorticosterone on Soluble Beef Heart Mitochondrial ATPase, Proo
Soc. exp. Biol. (N.Y.), 111, 529. 
BUSH, I. E. (1962): 'Chemical and Biological Factors in the Actions of Steroid Hormones' in the Human Adrenal Contex. Eds. A. R. Currie, T. Symington, and J. K. Grant, London: E. \& S. Livingstone.

Butenand, A., Gunther, H. and Turba, F. (1960): Primary Metabolic Effects of Testosterone, Z. Physiol. Chem., 322, 28.

Cantarow, A., Pashisiss, K. E., and Williams, T. L. (1959): Influence of Starvation on the Incorporation of Uracil-2-14C in Liver and Hepatoma Ribonucleic Acid, Biochim. biophys. res. Commun., 1, 75.

Chance, B., and Hollunger, G. (1963): Inhibition of Electron and Energy Transfer in Mitochondria. I. Effects of Amytal, Thiopental, Rotenone, Progesterone and Methylene Glycol, J. biol. Chem., 238, 418.

Clark, I. (1953): The Effect of Cortisone Upon Protein Synthesis, J. biol Chem., $200,69$.

Frieden, E. H., Laby, M. R., Bates, F., and Layman, N. W. (1957): The Effect of Testosterone Propionate Upon Incorporation of Labelled Glycine into Mouse Kidney Slices, Endocrinology, 60, 290.

Froesch, E. R., ASHMORE, J., and RENOLD, A. E. (1958): Comparison of Renal and Hepatic Effects of Fasting, Cortisone Administration and Glucose Infusion in Normal and Adrenalectomised Rats, Endocrinology, 62, 614.

Gallagher, C. H. (1960): The Mechanism of Action of Hydrocortisone on Mitochondrial Metabolism, Biochem., J., 74, 38.

GoldSTeid, L., Stella, E. J., and Knox, W. E., (1962): The Effect of Hydrocontisone on Tyrosine- $\alpha$ ketoglutarate Transaminase and Tryptophan Pyrrolase Activities in the Isolated, Perfused Rat Liver, J. biol. Chem., 237, 1723.

GreEngard, O. and Acs, G. (1962): The Effect of Actinomycin on the Substrate and Hormonal Induction of Liver Enzymes, Biochim. biophys. Acta (Amst.), 61, 652.

Hagerman, D. D., and Villee, C. A. (1957): Estrogen Sensitive Isocitric Dehydrogenase, J. biol. Chem., 229, 589.

Hagerman, D. D., and Villee, C. A. (1959): Separation of Human Placental Estrogen-Sensitive Transhydrogenase From Estradiol-17 $\beta$-Dehydrogenase, J.biol. Chem., 234, 2031.

Hagerman, D. D., and Villee, C. A. (1961): 'A Mechanism of Action for Estrogenic Steroid Hormones' in Mechanism of Action of Steroid Hormones. Eds. C. A. Villee and L. L. Engel. Oxford, London, New York and Paris: Pergamon Press.

Halkerston, I. D. K., EichHorn, J., Feinstein, M., Scully, E., and Hechter, O. (1960): Early Permeability Effects of Estradiol on Castrate Rat Uterus, Proc. Soc. exp. Biol. (N.Y.), 103, 796.

Hancock, R. L., Zelis, R. F., Shaw, M., and Williams-Ashman, H. G. (1962): Incorporation of Ribonucleoside Triphosphates into Ribonucleic Acid by Nuclei of the Prostate Gland, Biochim. biophys, Acta (Amst.), 55, 257.

HARPER, A. E. (1959): Hormonal Factors Affecting Glucose-6-phosphatase Activity. II. Some Effects of Diet and of Alloxan Diabetes in the Rat, Biochem. J., 71, 702.

HARPER, A. E., and YouNG, F. G. (1959): Hormonal Factors Affecting Glucose-6-phosphatase Activity. Effect of Hypophysectomy and Replacement Therapy in the Rat, Biochem. J., 71, 696.

Hechter, O., and Lester, G. (1960): 'Cell Permeability and Hormone Aotion', Recent Prog. Hormone Res., 16, 139.

Horton, H. R., and Franz, J. M. (1959): Effect of Ethionine on the Cortisone-Evoked Stimulation of Tryptophan Peroxidase-Oxidase Activity, Endocrinology, 64, 258.

HuRlock, B., and TAlalay, P. (1958): $3 \alpha$-hydroxysteroids as Coenzymes of Hydrogen Transfer between Di- and Triphosphopyridine Nucleotides, J. biol. Chem., 233, 886.

JACOB, F., and MONOD, J. (1961): Genetic Regulatory Mechanisms in the Synthesis of Proteins, J. mol. Biol., 3, 318

Jarabak, J., Adams, J. A., Williams-Ashman, H. G., and Talalay, P. (1962): Purification of a $17 \beta$-Hydroxysteroid Dehydrogenase of Human Placenta and Studies on its Transhydrogenase Function, J. biol. Chem., 237, 345 .

Joel, P. B., Hagerman, D. D., and Villee, C. A. (1961): Effects of Estradiol Added in vitro on the Metabolism of Human Placenta, J. biol. Chem., 236, 3151 .

Kaplan, N. O., Ciotti, M. M., Hamolsky, M. and Bieber, R. E. (1960): Molecular Heterogeneity and Evolution of Enzymes, Science, 131, 392.

KenNeY, F. T. (1962a): Induction of Tyrosine- $\alpha$-ketoglutarate Transaminase in Rat Liver. II. Enzyme Purification and Preparation of Antitransaminase, J. biol. Chem., 237, 1605.

KenNEY, F. T. (1962b): Induction of Tyrosine- $\alpha$-ketoglutarate Transaminase in Rat Liver. III. Immunochemical Analysis, J. biol. Chem., 237, 1610.

KENNEY, F. T., and FLORA, R. M. (1961): Induction of Tyrosine- $\alpha_{-}$-ketoglutarate Transaminase in Rat Liver. I. Hormonal Nature, J. biol. Chem., 236, 2699.

Kimberg, D. V., and Yielding, K. L. (1962): Pyruvate Kinase. Structural and Functional Changes Induced by Diethylstilbostrol and Certain Steroid Hormones, J. biol. Chem., 237, 3233.

Kochakian, C. D., Hill, J., and Aonuma, S. (1963): Regulation of Protein Biosynthesis in Mouse Kidney by Androgens, Endocrinology, 72, 354.

Kochakian, C. D., TANAKA, R., and Hill, J. (1961): Regulation of Amino Acid Activating Enzymes of Guinea Pig Tissues by Androgens, Amer. J. Physiol., 201, 1068.

KORNER, A. (1960): The Role of the Adrenal Gland in the Control of Amino Acid Incorporation into Protein of Isolated Rat Liver Microsomes, J. Endocr., 21, 177.

KvaM, D. C., and PARKES, R. E. (1960): Inhibition of Hepatic Induced Enzyme Formation by 8-azaguanine, J. biol Chem., 235, 2893.

LAIDLER, K. J., and KRUPKA, R. M. (1961): 'Enzyme Mechanisms in Relation to the Mode of Action of Steroid Hormones, in Mechanism of Action of Steroid Hormones. Eds. C. A. Villee and L. L. Engel. Oxford, London, New York and Paris: Pergamon Press. 
Liao, S., and Williams-Ashman, H. G. (1962): An Effect of Testosterone on Amino Acid Incorporatiof by Prostatic Ribonucleoprotein Particles, Proc. nat. Acad. Sci. (Wash.), 48, 1956

LOVELOCK, J. E., SimmondS, P. G., and VANDENHEUVEL, W. J. A. (1963): Affinity of Steroids for Electror with Thermal Energies, Nature (Lond.), 197, 249.

Lucas, F. V., Neufield, H A., UtTerback, J. G., Martin, A. P., and Stotz, E. (1955): The Effect of Estrogen on the Production of a Peroxidase in the Rat Uterus, J. biol. Chem., 214, 775.

MANCHESTER, K. L., RANDle, P., and Young, F. G. (1959): The Effect of Growth Hormone and of Cortisis on the Response of Isolated Rat Diaphragm to the Stimulating Effect of Insulin on Glucose Uptake and on Incorporation of Amino Acids, J. Endocr., 18, 395.

MCGuiRe, J., and PESCH, L. A., (1962): Control of Glucose Oxidation in Anterior Pituitary by Hormonale Sensitive Pyridine Nucleotide Transhydrogenase, Proc. nat. Acad. Sci. (Wash.), 48, 2157.

Metcalf, W. and Gross, E. (1960): Influence of Anabolic Steroids on Uptake of Alpha-aminoisobutyr

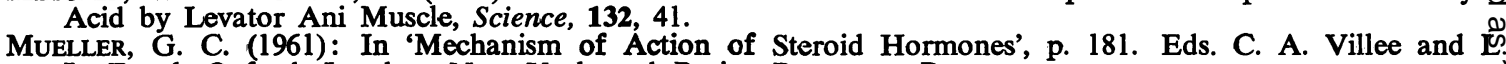
L. Engel. Oxford, London, New York and Paris: Pergamon Press.

Mueller, G. C., Herranen, A. M., and Jervell, K. F. (1958): Studies on the Mechanism of Action of Estrogens, Rec. Prog. Hormone Res., 14, 95.

Noall, M. W., and Allen, W. M. (1961): Early Stimulation by Estradiol of Amino Acid Penetration in Rabbou Uterus, J. biol. Chem., 236, 2987.

Noall, M. W., Riggs, T. R., Walker, L. M., and Christensen, H. N. (1957): Endocrine Control @ Amino Acid Transfer, Science, 126, 1002.

Pesch, L. A., Piros, K., and Klatskin, G. (1962): Effect of Estrogen in vitro on Particulate Pyridine Nucleotide Transhydrogenase Activity of Rat Liver, Biochim. biophys. Acta (Amst.), 62, 602.

Pettenglll, O., and Fishman, W. H. (1960): Endocrine Soc. Meeting, Miami, June, 1960, quoted b Fishman, W. H. (1961): In 'Renal $\beta$-glucuronidase Response to Steroids of the Androgen Series' ing Mechanism of Action of Steroid Hormones. Eds. C. A. Villee and L. L. Engel, Oxford, London, Ne York and Paris: Pergamon Press.

RiotTon, G., and FishmaN, W. H. (1953): $\beta$-Glucuronidase Studies in Inbred Mice: Androgenic Hormon\& and Kidney and Urinary $\beta$-glucuronidase Activity, Endocrinology, 52, 692.

RoberTS, S., and SzEgo, C. M. (1953): The Influence of Steroids on Uterine Respiration and Glycolysis, biol. Chem., 201, 21.

Rosen, F., ROBERTS, N. R., and NichOl, C. A. (1959): Glucocorticosteroids and Transaminase Activity I. Increased Activity of Glutamic-pyruvic Transaminase in Four Conditions Associated with Gluce neogenesis, J. biol Chem., 234, 476.

SCOTT, J. F., and ENGEL, L. L. (1961): Interactions between Steroid Hormones and other Biologically Impora Substances, in Mechanism of Action of Steroid Hormones. Eds. C. A. Villee and L. L. Engel, Oxfard, London, New York and Paris: Pergamon Press.

Segal, H. L., BeATtIe, D. S., and HopPER, S. (1962): Purification and Properties of Liver Glutamic-alamin Transaminase from Normal and Corticoid-treated Rats, J. biol. Chem., 237, 1914.

Segal, H. L., Rosso, R. G., Hopper, S. and Weber, M. M. (1962): Direct Evidence for an Increase Enzyme Level as the Basis for the Glucocorticoid-induced, Increase in Glutamic-alanine Transamina Activity in Rat Liver, J. biol. Chem., 237, 3303.

Stein, A. M., and KAPLAN, N. O. (1959): Relationship of $3 \alpha$-hydroxysteroid Dehydrogenase to Pyridine Nucleotide Transhydrogenase, Science, 129, 1611.

Talalay, P., Hurlock, B., and Williams-Ashman, H. G. (1958): A Coenzymic Function of Estradiol-17 $\mathbb{R}$ Proc. nat. Acad. Sci. (Wash.), 44, 862.

Talalay, P., and Williams-Ashman, H. G. (1958): Activation of Hydrogen Transfer between Pyridia Nucleotides by Steroid Hormones, Proc. nat. Acad. Sci. (Wash.), 44, 15.

Talalay, P., and Williams-Ashman, H. G. (1960): Participation of Steroid Hormones in the Enzymatic Transfer of Hydrogen, Rec. Prog. Hormone Res., 16, 1.

Tissieres, A., SCHLESSINGER, D., and GROS, F. (1960): Amino Acid Incorporation into Proteins bij, Escherichia coli Ribosomes, Proc. nat. Acad. Sci. (Wash.) 46, 1450.

TomkINS, G. M., and MAXwell, E. S. (1963): Some Aspects of Steroid Hormone Action, Ann. Rev. Biष chem., 32, 677.

WADE, R., and JONES, H. W. (1956): Effect of Progesterone on Oxidative Phosphorylation, J. biol. Chem. $220,553$.

WestPHAL, U. (1961): Interactions between Steroids and Proteins in 'Mechanism of Action of Steroid Ho mones.' Eds. C. A. Villee and L. L. Engel, Oxford, London, New York and Paris: Pergamon Press.

Williams-Ashman, H. G., Cassman, M., and Klavins, M. (1959): Two Enzymic Mechanisms for Hydrogenf Transport by Phenolic Oestrogens, Nature (Lond.), 184, 427.

White, A., Hoberman, H. D., and SzEgo, C. M. (1948): Influence of Adrenalectomy and Fasting on the Incorporation of Isotopic Nitrogen into the Tissues, J. biol. Chem., 174, 1049.

WiLson, J. D. (1962a): Localisation of the Biochemical Site of Action of Testosterone on Protein Synthesien in the Seminal Vesicle of the Rat, J. clin. Invest., 41, 153.

Wilson, J. D. (1962b): Regulation of Protein Synthesis by Androgens and Oestrogens, in 'Protein Metabolissa Influence of Growth Hormone, Anabolic Steroids and Nutrition in Health and Disease'. Ed. F. Gross, p. 26. Berlin: Springer Verlag.

YIELDING, K. L. and TomKINS, G. M. (1962): Studies on the Interaction of Steroid Hormones with Glutamic Dehydrogenase, Rec. Prog. Hormone Res., 18, 467.

Yielding, K. L., Tomkins, G. M., Munday, J. S., and Cowley, I. J. (1960): The Effect of Steroids of Electron Transport, J. biol. Chem., 235, 3413. 